young is not a possible explanation because the young seldom, if ever, leave their burrows during the first month or two. Nor does it seem likely that the parents are involved, since the feet of the young shearwaters are kept under the body and hidden by down.

Review of much of the literature on shearwaters has revealed no mention of holes in their webs although I know others have observed the condition here. It is possible that this is a local condition in these Hawaiian populations, where the species or large numbers of the parasitic fly might explain the frequency of holes in webs. The result is probably of no disadvantage to the adult birds in their swimming except in those few cases in which perforation progresses to an extent such as shown in the photograph.Frank Richardson, Department of Zoology and Entomology, University of Hawaii, Honolulu, Hawaii.

\title{
Seventh Pacific Science Congress
}

\author{
FEBRUARY 2 TO 23, 1949
}

To be held at AUCKLAND and CHRISTCHURCH, NEW ZEALAND. Under the auspices of the Royal Society of New Zealand, and with the assistance of the Government of New Zealand.

\section{ORGANIZATION}

The Pacific SCIENCE Association has accepted the invitation of the Royal Society of New Zealand to hold the Seventh Pacific Science Congress in New Zealand in 1949. The forthcoming Congress has the same scope and purpose as those previously held, i.e., Honolulu (1920), Sydney and Melbourne (1923), Tokyo and Kyoto (1926), Batavia and Bandoeng (1929), Vancouver and Victoria (1932), and Berkeley, Palo Alto, and San Francisco (1939).

The Royal Society of New Zealand has appointed an Organizing Committee charged with the general arrangements for the Congress, with responsibility for perfecting the program and for local arrangements in Auckland and Christchurch.

\section{MEMBERSHIP}

The Pacific Science Association has a membership of 46 countries; i.e., those within or bordering the Pacific or having territorial responsibilities therein, and those which have carried out research in the Pacific. Each country holds membership through a Representative Institution, i.e., its National Academy or National Research Council, or organization of similar status.

Personal membership of the Congress is under three categories:

\section{Official Members}

(1) Official delegates representing the constituent countries of the Pacific Science As- sociation, restricted in number as determined by the Association.

(2) Delegates otherwise accredited to the Congress by the governments of the participating countries or by agencies of those countries corresponding to the Royal Society of New Zealand.

(3) Officers and honorary officers of the Congress, members of the Organizing Committee, chairmen and secretaries of standing committees of the Pacific Science Association, and chairmen of committees and sections.

(4) Persons specially invited to attend by the President of the Congress.

\section{Members}

Members include those persons, other than official members, who are accredited to the Congress by scientific societies, universities, and other research organizations. Members will be accorded full privileges of the Congress.

\section{Participants}

This category includes all other registered attendants at the Congress, including ladies accompanying official members and members. Participants will be accorded full privileges of the Congress except that official members and members will be given preference in housing accommodation and on excursions. The registration fee for New Zealand participants will be $£ 1: 1: 0$. 
To permit the Organizing Committee to make suitable provisions, each Representative Institution is requested to send to the Secretary of the Congress at the earliest possible date the names and addresses of all official members, members, and participants who are expected to attend the Congress.

\section{PUBLICATIONS}

Handbooks and Program will be issued to all members; the Proceedings of the Congress will be issued to Representative Institutions and official members. Members and participants may purchase the Proceedings at cost price.

\section{PROGRAM ORGANIZATION}

Ten divisions representing different sciences have been organized and divisional meetings for discussion of papers of divisional interest will be held. [The ten divisions under which the meetings will be organized are: (1) Geophysics and Geology; (2) Meteorology; (3) Oceanography and Marine Biology; (4) Zoology; (5) Botany; (6) Soil Resources and Agriculture; (7) Anthropology; (8) Public Health and Nutrition; (9) Social Sciences; (10) Organization of Research.] The Program will, however, give chief place to symposia on special topics of interest to two or more divisions. A first draft of the program has been sent to Representative Institutions; the final program will be arranged after hearing their views. [The final program will be published in the October number of PACIFIC SCIENCE if it is available in time-Ed.]

\section{Patron \\ OFFICERS OF THE CONGRESS}

His Excellency the Governor-General of New Zealand, Sir Bernard Freyberg, V.C., G.C.M.G., K.C.B., K.B.E., D.S.O.

\section{Honorary Presidents}

The Right Hon. P. Fraser, C.H., Prime Minister of New Zealand.

The Hon. T. H. McCombs, Minister of Scientific and Industrial Research.

\section{Honorary Vice-Presidents}

His Worship the Mayor of Auckland, J. A. C. Allum, Esq., C.B.E.

His Worship the Mayor of Christchurch, E. H. Andrews, Esq., C.B.E.

Herbert E. Gregory, President of the First Pan-Pacific Science Congress.

H. M. Tory, President of the Fifth Pacific Science Congress.

Ross G. Harrison, President of the Sixth Pacific Science Congress.

\section{President}

R. A. Falla, President of the Royal Society of New Zealand.

Secretary-General

Gilbert Archey, Director, Auckland Institute and Museum, Auckland. Cable Address: CONGRESS AUCKLAND.

The Secretary-General will welcome inquiries or suggestions from intending members or participants, or from scientific institutions.-Gilbert Archey, Secretary-General, Seventh Pacific Science Congress.

\section{Further Information Concerning the Fulbright Act}

THE FOLLOWING SUMMARY of information, available to date, concerning the implementation of the Fulbright Act has been received from Harold J. Coolidge, Executive Secretary of the Pacific Science Board of the National Research Council.

The Fulbright Act (Public Law No. 584) authorizes the Department of State to use a portion of the foreign currencies resulting from the sale of surplus property abroad for purposes of educational interchange and activities with foreign countries.

At present agreements have been signed with only two countries-China and Burma; but negotiations are in progress with the following: Australia, Austria, Belgium, Czechoslovakia, Egypt, Finland, France, Greece, Hungary, Iran, Italy, the Netherlands, the Netherlands East In- dies, New Zealand, Norway, the Philippines, Siam, Turkey, the United Kingdom, and it is expected that other countries may be added to the list.

It should be stressed that since the money available is only in foreign currencies and is not convertible to American dollars, individual arrangements must be made for each American participating in the program for such dollar balances as he will require to meet his family needs and other obligations in the United States during the period of his absence abroad.

While the term educational interchange may be interpreted very broadly, the following amplification will serve as a more useful guide to the types of activities envisaged:

Aid in international reconstruction by assisting foreign countries to secure the services of 